\section{Degenerin similarities}

SIR - We were delighted to hear, before publication on 4 February, that Canessa et al. ${ }^{1}$ had identified a gene whose product, $\alpha \mathrm{rENaC}$, conveys amiloride sensitivity on Xenopus oocytes and exhibits extensive similarity to two Caenorhabditis elegans genes, deg-1 (ref. 2) and mec-4 (ref. 3), that can mutate to produce neuronal degeneration. We have called the products of these $C$. elegans genes degeneris ${ }^{3}$. Here we would like to point out that the similarity extends further than what is evident from our previously published sequences, demonstrating that the mammalian and $C$. elegans genes are members of the same gene family.

We have been able to obtain fulllength coding sequences of the mec-4 gene and of a new member of the degenerin family, mec-10 (see figure). The sequences predict proteins of 768 and 724 amino acids, respectively. The mec-10 protein has the two cysteine-rich domains and carboxy-terminal hydrophobic domain previously noted in the mec-4 protein sequence ${ }^{3}$. In addition, the mec-4 and mec-10 proteins have a second hydrophobic domain approximately 100 amino acids from the aminoterminus and regions of similarity both before and after this putative membranespanning region. This more aminoterminal hydrophobic region and the associated conserved sequences are also found in the rat $\alpha \mathrm{rENaC}$ protein ${ }^{1}$. Thus, all three proteins have a similar structure and exhibit regions of similarity over their entire lengths, indicating that they are members of the same gene family (although the rat protein does not have the more amino-terminal cysteine-rich region).

The finding that $\alpha \mathrm{rENaC}$ can convey amiloride-sensitivity to Xenopus oocytes raises the intriguing possibility that mec4 , mec-10 and, presumably, deg- 1 also encode subunits of a similar sodiumchannel complex. This is particularly exciting because mec- 4 and mec-10 were first identified by virtue of mutations that caused $C$. elegans to be touchinsensitive $e^{4,5}$ and because these genes

1. Canessa, C. M., Horisberger, J.-D. \& Rossier, B. C Nature 361, 467-470 (1993).

2. Chalfie, M. \& Wolinsky, E. Nature $\mathbf{3 4 5}, \mathbf{4 1 0 - 4 1 6}$ (1990)

3. Driscoll, M. \& Chalfie, M. Nature $349,588-593$ (1991)

4. Chalfie, M. \& Sulston, J. Devl Biol. 82, 358-370 (1981).

5. Chalfie, M. \& Au, M. Science 243, 1027-1033 (1989).

6. Jørgensen, F. O. Acta Physiol. Scand. (Abstr. Scand. Physiol. Soc. Meet.) 25-26A (1978)

7. Jørgensen, F. \& Ohmori, H. J. Physiol., Lond. 403. $577-588$ (1988)

8. Lane, J. W., McBride, D. W. Jr \& Hamill, O. P. J. Physiol. Lond. 441, 347-366 (1991)

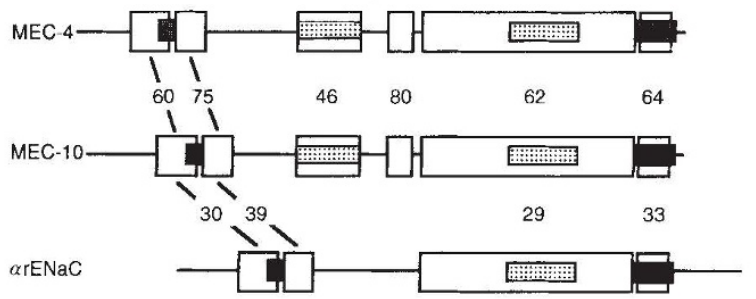

Region of similarity Cysteine-rich Hydrophobic

Comparison of the predicted protein sequences of MEC-4, $\mathrm{MEC}-10$, and $\alpha \mathrm{rENaC}$. Regions of similarity have at least $25 \%$ sequence identity compared to MEC-10; exact values are indicated in the figure. MEC-4 and $\alpha \mathrm{rENaC}$ share the same four regions of similarity that MEC-10 and arENaC do (the corresponding percentages of identity, starting at the amino termini, are 30, 36, 23 and 31). The arENaC sequence was generously provided by $\mathrm{B}$. Rossier before publication $^{1}$. Scale bar, 100 amino acids.

have been hypothesized to be part of the mechanosensory transduction machinery ${ }^{3,5}$. These genes (and the mec-6 gene, which is needed for touch sensitivity ${ }^{4,5}$ and for the mec-4and deg- 1 -dependent degenerations ${ }^{2}$ ) may be part of a mechanotransducing channel.

It is likely, given the fact that several members of this family are found in $C$.

either naturally or through mutation.

Martin Chalfle

Monica Driscoll*

Mingxla Huang

Department of Biological Sciences,

Columbia University,

New York, New York 10027, USA

*Also at Department of Molecular Biology and Biochemistry, Center for Advanced Biotechnology and Medicine, Rutgers University, Piscataway, New Jersey 08855, USA

\section{Sex surveys and drug users}

SIR - The British national survey of sexual attitudes ${ }^{1}$ and the French national telephone survey ${ }^{2}$ provide general population norms for sexual behaviour, giving a control group "against which research in more focused populations at high risk (of HIV) ... can be assessed"1. One such population is injecting drug users, who are recognized as a source of heterosexual spread of HIV infection. While it is widely believed that drug users who take depressants (for example, opiates and tranquillizers) practise less sexual intercourse than the norm ${ }^{3}$, such assertions have been at best speculative because it has been difficult to relate such behaviour to general population norms.

Between May 1990 and December 1991 (fortuitously identical to the time period of the British survey), 919 of Glasgow's estimated 9,400 injecting drug and community-wide sampling strategy was implemented to provide as representative a sample as possible of injecting drug users in Glasgow. Respondents, of whom $88 \%$ injected daily and $99 \%$ users were investigated ${ }^{4}$. A multicentre

NUMBER OF HETEROSEXUAL PARTNERS BY AGE AND GENDER

\begin{tabular}{|c|c|c|c|c|c|c|c|c|}
\hline & \multicolumn{4}{|c|}{ Men } & \multicolumn{4}{|c|}{ Women } \\
\hline & \multicolumn{2}{|c|}{$16-24$} & \multicolumn{2}{|c|}{$25-34$} & \multicolumn{2}{|c|}{$16-24$} & \multicolumn{2}{|c|}{$25-34$} \\
\hline & Glasgow & Ref. 1 & Glasgow & Ref. 1 & Glasgow & Ref. 1 & Glasgow & Ref. 1 \\
\hline None & $16.1 \% *$ & $26.9 \%$ & $17.6 \% *$ & $8.6 \%$ & $19.6 \%$ & $23.9 \%$ & $27.6 \% *$ & $6.7 \%$ \\
\hline One & $46.1 \%$ & $46.2 \%$ & $52.7 \% *$ & $76.9 \%$ & $62.7 \%$ & $60.5 \%$ & $58.6 \% *$ & $86.8 \%$ \\
\hline Two & $12.7 \%$ & $14.3 \%$ & $10.1 \%$ & $8.6 \%$ & $8.9 \%$ & $10.0 \%$ & $8.0 \%$ & $4.9 \%$ \\
\hline $3-4$ & $16.4 \% *$ & $9.1 \%$ & $10.5 \% *$ & $4.1 \%$ & $7.6 \%$ & $4.5 \%$ & $3.4 \%$ & $1.3 \%$ \\
\hline $5+$ & $8.6 \% *$ & $3.5 \%$ & $9.1 \% *$ & $1.9 \%$ & $1.3 \%$ & $1.0 \%$ & $2.3 \%$ & $0.3 \%$ \\
\hline $\begin{array}{l}\text { 99th } \\
\text { centile }\end{array}$ & 12 & 10 & 20 & 5 & 5 & 7 & 5 & 3 \\
\hline Mean & $1.9 *$ & 1.4 & $2.0^{*}$ & 1.2 & 1.1 & 1.0 & 0.9 & 1.0 \\
\hline Variance & 4.7 & 5.2 & 13.3 & 8.9 & 0.9 & 1.8 & 0.7 & 0.3 \\
\hline$N$ & 347 & 1,984 & 296 & 2,167 & 158 & 2,246 & 87 & 2,899 \\
\hline
\end{tabular}

The table is a comparison between the study reported here (Glasgow) and the British survey (ref. 1). Number of partners are in the past 6 months for the Glasgow study and the past year for ref. 1. Sexual activity resulting from prostitution was excluded from the Glasgow study.

* Significant difference between the Glasgow study and ref. $1(P<0.05)$ 